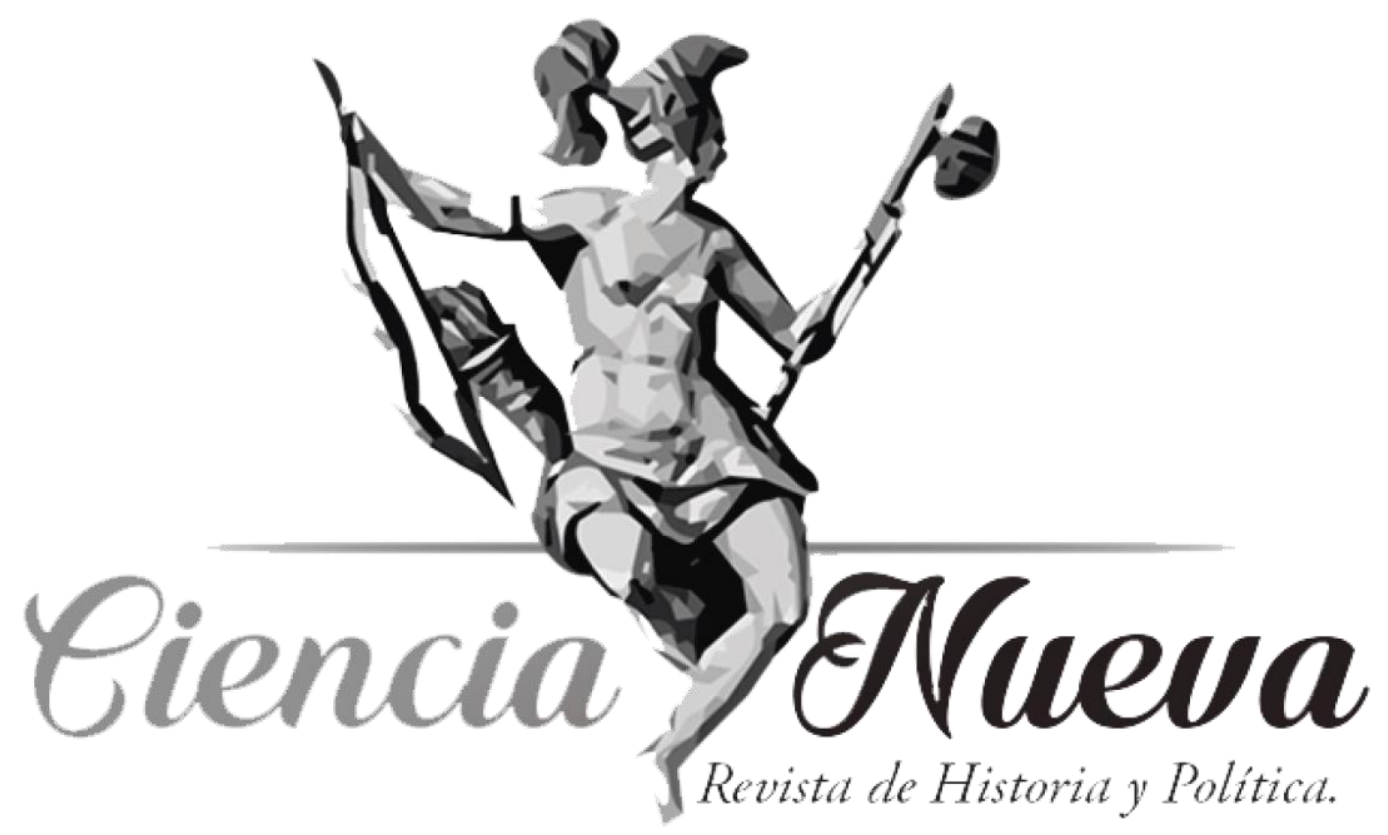

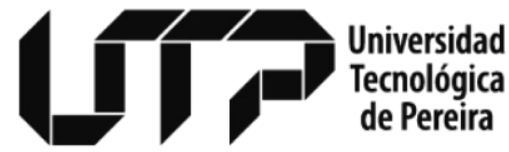

Maestría en Historia

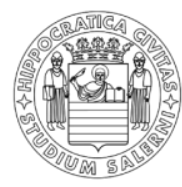

UNIVERSITÀ DEGLI STUDI DI SALERNO

DOSSIER

GLOBAL PERSPECTIVES OF LATIN-AMERICAN HISTORY Daniel Emilio Rojas Castro (MCF), Guest Editor

A GLOBAL POSTAL SERVICE: EMPIRE, REFORM AND CONFLICT IN THE SPANISH ATLANTIC IN THE $18^{\text {TH }}$ CENTURY UN SERVICIO POSTAL GLOBAL: IMPERIO, REFORMA Y CONFLICTO EN EL ATLÁNTICO ESPAÑOL EN EL SIGLO XVIII DOI: https://doi.org/10.22517/25392662.22651

Rocío Moreno Cabanillas pp. $94-111$

Vol. 3 Núm. 1 | Enero-Junio de 2019

Pereira, Colombia 


\title{
A GLOBAL POSTAL SERVICE: EMPIRE, REFORM AND CONFLICT IN THE SPANISH ATLANTIC IN THE 18TH CENTURY*
}

\author{
UN SERVICIO POSTAL GLOBAL: IMPERIO, REFORMA Y CONFLICTO EN EL \\ ATLÁNTICO ESPAÑOL EN EL SIGLO XVIII
}

\author{
Rocío Moreno Cabanillas ${ }^{* *}$ \\ rmorcab@upo.es
}

ORCID: http://orcid.org/0000-0001-5579-3712

$\begin{array}{cl}\text { Received: } & \text { February } 18^{\text {th }}, 2019 . \\ \text { Reviewed: } & \text { March } 22^{\text {th }}, 2019 . \\ \text { Accepted: } & \text { June } 19^{\text {th }}, 2019 . \\ \text { Published: } & \text { June } 30^{\text {th }}, 2019 .\end{array}$

\begin{abstract}
:
In the $18^{\text {th }}$ century there was a general interest in the overseas European empires to institutionalize the postal system. The Spanish Monarchy, under the paradigm of the Bourbon Reforms, promoted a project to reform the Spanish-American mail in the second half of the $18^{\text {th }}$ century with the aim of making overseas communications more organized and regular. However, these plans for renewal came up against limits and power struggles between different agents interested in the circulation of information. This is reflected in the postal administration of Cartagena de Indias, which was a fundamental nucleus for the Crown where the interests of the different local and global powers converged, and where the difficulty of dominating the Spanish empire can be seen. This article analyses the contradictions and discrepancies of the postal reform project, examining it in a polycentric key through the communications node of the city of Cartagena de Indias.
\end{abstract}

Keywords: Atlantic World, history of mail, Bourbon Reforms, Global History, Colonial Spanish America, early modern world, circulation of information.

\section{Resumen:}

En el siglo XVIII se produjo un interés general en los imperios europeos ultramarinos por institucionalizar el sistema postal. La Monarquía Hispánica, bajo el paradigma de las reformas borbónicas, impulsó un proyecto de reforma del correo hispanoamericano en la segunda mitad del siglo XVIII con el objetivo de que las comunicaciones ultramarinas fuesen más organizadas y regulares. Sin embargo, estos planes de renovación se encontraron con límites y luchas de poder entre distintos agentes interesados en la circulación de la información. Ello se refleja en la administración de correos de Cartagena de Indias que era un núcleo fundamental para la Corona donde confluían los intereses de los distintos poderes locales y globales, y donde se puede ver la dificultad de dominio del imperio hispánico. En definitiva, este artículo analiza las contradicciones y discrepancias del proyecto de reforma postal que aquí examinamos en clave policéntrica a través del nodo de comunicaciones de la ciudad de Cartagena de Indias.

Palabras clave: Mundo Atlántico, historia del correo, Reformas Borbónicas, Historia Global, Hispanoamérica, historia moderna, circulación de la información.

\footnotetext{
* This research is developed within the research project called RES PÚBLICA MONÁRQUICA. LA MONARQUÍA HISPÁNICA, UNA ESTRUCTURA IMPERIAL POLICÉNTRICA DE REPÚBLICAS URBANAS (PGC2018-095224-B-I00) funded by the Ministerio de Ciencia, Innovación y Universidades of Spain and within the research group ESTUDIOS SOBRE EUROPA, EL MUNDO MEDITERRÁNEO Y SU DIFUSIÓN ATLÁNTICA (HUM-680) funded by the Junta de Andalucía. This paper was written according to the Declaration on Publication Ethics of Ciencia Nueva, Revista de Historia y Política. This Declaration can be read on the journal's website: revistas.utp.edu.co/index.php/historia.

** University Pablo de Olavide (Seville, Spain), PhD. in History and Humanistic Studies. Historian; Bachelor of Humanities from the University Pablo de Olavide (UPO, Seville, Spain). Master's in History of Europe, the Mediterranean World and its Atlantic Diffusion. Methods, theories and new lines of research from the UPO and Master's Degree in Teaching Compulsory Secondary Education and Baccalaureate, Vocational Training and Language Teaching. Social Sciences Specialty: Geography and History from the UPO.
} 


\section{Introduction}

$\mathrm{T}$

This paper examines the reform project of the postal system that the Bourbon Monarchy planned in the second half of the $18^{\text {th }}$ century in which they enacted changes in an attempt to exert state control. These reform plans collided with particular interests and led to negotiations with various stakeholders. In fact, the postal administration would become a focal point for the struggle between central and local power and crucial to the political, economic and social control of the Spanish American territories. In this article, the Bourbon Reforms are analyzed through the lens of the postal system, where different contributors shaped these renewal projects according to their interests. This paper analyzes the limits of these reforms and the competition for postal control that occurred in Spanish America in the $18^{\text {th }}$ century. These restrictions and struggles have been examined through the study of conflict scenarios and the challenges of the implementation of the postal reform in Cartagena de Indias that revealed the competition and interest in dominating the circulation of information. Moreover, this research demonstrates how social dynamics intervened in the configuration and intervention of the postal administration of Cartagena de Indias in a context of multiple and flexible interests, and strategies that moved between cooperation and conflict. Therefore, the postal reform had to negotiate and dispute its attributions within the colonial society with the various participants involved in the circulation of information. Simultaneously, this study reveals how the polycentric monarchy continued to be the main key to the stability of the empire in the $18^{\text {th }}$ century.

Communication was a crucial aspect to the functioning of the Spanish empire. The circulation of information was essential in governing the territories and to maintaining social, economic, political and cultural relations in these empires. Furthermore, the systems that circulated information, as in the case of the postal system, produced modification in policies, practices and networks. All these aspects were of fundamental relevance in the formation and the maintenance of the European empires.

According to historiography, the postal service had a fundamental role in the government of the empires. An important moment in the Spanish empire was in the $18^{\text {th }}$ century, as part of the larger Bourbon Reforms as the Spanish Monarchy sought to establish a new model of sovereignty with these reform plans. The Bourbon Monarchy included in their plans the innovation of the mail system that promised to allow the shrinking of the vast Spanish empire by quickening communications and strengthening the bureaucratic chain of command ${ }^{1}$. Nevertheless, these projects encountered obstacles and resistances both in the Iberian Peninsula and in their overseas locations. All these facts are essential to understanding the complex structure of a monarchy that has recently been defined as polycentric ${ }^{2}$. The networks of correspondence were crucial to understanding the empire and thus the ability of historians to explain the functioning of the polycentric monarchy. In this sense, current research has promoted a new interpretation based on the connections between different networks and the consensus between the different centers and agents of power as

\footnotetext{
${ }^{1}$ Sylvia Sellers-García, "The mail in Time: Postal Routes and Conceptions of Distance in Colonial Guatemala”, Colonial Latin American Review 21, n. ${ }^{\circ} 1$ (2012): 77.

${ }^{2}$ For a discussion of the history and an extended analysis on polycentric monarchies see Pedro Cardim et al., How Did Early Modern Spain and Portugal Achieve and Maintain a Global Hegemony? (Eastbourne: Sussex Academic Press/Fundación Séneca/Universidade Nova de Lisboa-CHAM/Red Columnaria, 2012).
} 
practices of real exercise ${ }^{3}$. Studies on the polycentric model have focused on the $16^{\text {th }}$ and $17^{\text {th }}$ centuries. It is therefore necessary to analyze how this analytical paradigm worked in the later period, in the $18^{\text {th }}$ century, under the Bourbon Monarchy in the Spanish empire.

\section{Postal System Reform in a global framework}

The postal system was an essential tool for connecting different territories in a global space during the early modern $\mathrm{era}^{4}$. The circulation of information in early modern times is structured within a global and linked framework centered on the study of relations, connections and networks of various kinds between different spaces on a world scale. These circulations and connections were fundamental in establishing global approaches as they allowed large areas of differing political and cultural identity to be brought together through a relational space, such as the Atlantic Ocean. The Atlantic was considered a porous border based on a complex mosaic of interrelated and multidirectional sociopolitical, cultural and commercial networks ${ }^{5}$. Through this framework, the post appears as an essential means of connecting distant places and geographical contexts, as was the case with European empires and their overseas territories.

In the early modern era, the post was the primary public means of both communication and transportation and thus was essential to news networks ${ }^{6}$. The early modern post was a business that collected and delivered mail, transported passengers and infrequently goods and money. The postal routes were fixed and were composed of post offices, relays and workers, and available to the public.

European powers began to make postal services available to members of the public and discovered in the post not only a source of revenue, but a very effective means of ensuring security by eliciting and controlling the speech of their subjects. The comparative perspective that induces globalization suggests that the circumstances of different states are ordered according to a synchronized time axis ${ }^{7}$. From the second half of the $17^{\text {th }}$ century, and especially in the $18^{\text {th }}$ century, the Atlantic monarchies promoted a series of reforms aimed at

\footnotetext{
${ }^{3}$ See Manuel Herrero Sánchez, "The business relations, identities and political resources of Italian merchants in the early-modern Spanish monarchy: some introductory remarks", European Review of History: Revue européenne d'histoire 23, n. ${ }^{\circ} 3$ (2016): 335-346; Regina Grafe, "Polycentric States: The Spanish Reigns and the "Failures" of Mercantilism", in Mercantilism Reimagined: Political Economy in Early Modern Britain and its Empire (Oxford: Oxford University Press, 2013): 241-262; and Manuel Pérez García \& Lucio De Sousa, eds., Global history and new polycentric approaches. Europe, Asia and the Americas in a World Network System (Singapore: Palgrave Macmillan, 2018).

${ }^{4}$ For global history see Maxine Berg, Writing the History of the Global. Challenges for the 21st Century (Oxford: The British Academy, 2013); Sebastian Conrad, What is global history? (Princeton: Princeton University Press, 2016); Daniel Emilio Rojas, ed., Amérique Latine Globale. Histoire connectée, globale et international (París: L'Harmattan, 2017); Sanjay Subrahmanyam, "Em busca das origens da histórica global", Estudos Historicos 30, n. ${ }^{\circ} 60$ (2017): 219-240; Bernd Hausberger, Historia mínima de la globalización temprana (México: El Colegio de México, Centro de Estudios Históricos, 2018).

${ }^{5}$ See Ralph Bauer and Marcy Norton, "Introduction: entangled trajectories: indigenous and European histories", Colonial Latin American Review 26, n. ${ }^{\circ} 1$ (2017): 1-17; Jorge Cañizares-Esguerra, Entangled Empires. The Anglo-Iberian Atlantic, 1500-1830 (Pennsylvania: University of Pennsylvania Press, 2018).

${ }^{6}$ Joad Raymond and Noah Moxham, News Networks in Early Modern Europe (Leiden/Boston: Brill, 2016), 19.

${ }^{7}$ Hugo Fazio Vengoa, Escenarios globales: el lugar de América Latina (Bogotá: Ediciones Uniandes, 2003).
} 
a more systematic imperial policy ${ }^{8}$. In this context, there were attempts at improvements in transportation and communication by the quickening of business and political affairs ${ }^{9}$.

European empires, such as Britain, France, Spain and Portugal, wanted the government to exercise an increased control in the postal system through a greater bureaucracy and organization in this service ${ }^{10}$. The British empire was the first to endeavor to establish a direct administration of the postal system between 1660 and 1711. After failed attempts, temporary measures and resistances, in 1711 the Post Office Act was enactment and the American colonies were incorporated into the British imperial postal system with England, Ireland and Scotland ${ }^{11}$. The French empire also promoted postal reform from the second half of the $17^{\text {th }}$ century and it was established in the $18^{\text {th }}$ century ${ }^{12}$. In the Portuguese Empire, the establishment of the overseas posts between Portugal and Brazil occurred in 1798 and followed the pattern of the British and Spanish states ${ }^{13}$.

The postal system was a highly sensitive and strategically important infrastructure system for the Spanish government, for this reason the government attempted to turn the postal service from an open network into a closed system. Part of the process of a network becoming a system involves the degree to which durability and consistency will be imparted to the network. Hence, the government wanted a monopolizing communication where the monarch was able to ensure that theirs was the most extensive network of power ${ }^{14}$.

However, it encountered a tension between state control and public service that was at the core of the postal system and at the heart of the state itself. The reason was the existence of the many economic, politic and social interests in the forces of the empires. Although the aim was a monopoly and centralization of the postal system, the government could not prevent the existence of other organizations that had their own post or messenger services such as merchants, The Church, The Inquisition to mention a few ${ }^{15}$. These actors were intermediators of the information of the empires and they found in the mail many opportunities to insert their own interests ${ }^{16}$. Thus, the possession of the mail created tensions between different participants interested in the circulation of information with the model of power shifting between negotiation and resistance.

\footnotetext{
${ }^{8}$ Clément Thibaud, "Pour une histoire polycentrique des républicanismes atlantiques (années 1770 - années 1880)", Revue d'histoire du XIXe siècle, n. ${ }^{\circ} 56$ (2018): 161.

${ }^{9}$ Muriel Le Roux and Sebastian Richez, Post Offices of Europe 18th - 21st Century. A Comparative History (PIE - Peter Lang S.A., 2014); Daniel R. Headrick, "Transportation and communication, 1750 to the present", in The Cambridge World History (Cambridge: Cambridge University Press, 2015), 401-422;

${ }^{10}$ Jay Caplan, Postal culture in Europe 1500-1800 (Oxford: Voltaire Foundation, 2016).

${ }^{11}$ For more information see Ian K. Steele, English Atlantic, 1675-1740: An Exploration of Communication and Community (New York: University of Oxford Press, 1986); Konstantin Dierks, In My Power Letter Writing and Communications in Early America (Philadelphia: University of Pennsylvania Press, 2009); Alejandra Dubcovsky, Informed power. Communication in the Early American South (Cambridge, Massachusetts and London: Harvard University Press, 2016)

${ }^{12}$ Kenneth Banks, Chasing empire across the sea: communications and the state in the French Atlantic, 17131763 (Montreal: McGill-Queen's University Press, 2006).

${ }^{13}$ For more information see Margarida Sobral Neto, As comunicaçoes na Idade Moderna (Lisboa: Fundação Portuguesa das Comunicações, 2005); Mayra Guapindaia, "Comunicação e poder: a implantação do Correio Marítimo de 1798 e as respostas dos governos da América Portuguesa", Nuevo Mundo Mundos Nuevos, (2017), doi: 10.4000/nuevomundo.71539.

${ }^{14}$ Patrick Joyce, The state of the freedom (Cambridge: Cambridge University Press, 2013).

15 Joad Raymond and Noah Moxham, News Networks..., 45.

${ }_{16}$ Arendt Brendecke, Imperio e Información. Funciones del saber en el dominio colonial español (Madrid: Iberoamericana, 2012).
} 


\section{The configuration of a new mail service in the Spanish empire}

The Bourbon Monarchy promoted a major effort to rethink the nexus of political, fiscal, economic, social, and religious relationships within the Spanish Atlantic system ${ }^{17}$. Notably it promoted policies to strengthen Madrid's authority. In this context, the monarchy was interested in controlling the postal communications to more effectively govern its American dominions. However, this idea of centralization, collided with reality as these reform plans were modified and adapted in each place to the local circumstances. These modifications of the original reform plans questioned the process of centralization ${ }^{18}$. Therefore, it is essential to understand why and how the renovation projects were forged that configured a new concept of monarchy where theoretical ambitions were disseminated and disfigured in practical applications.

In the Spanish empire, the Bourbon crown tried to establish an effective royal mail service, which greatly improved and regularized communication throughout the Spanish Atlantic empire ${ }^{19}$. The incorporation of the mail aimed to improve communication and make its passage more profitable. These improvements intended to allow for more effective administration and more accountability to the central government, according to the Bourbon policy initiative. The postal reform began in 1764 with the publication of the Reglamento Provisional del Correo Marítimo de España a sus Indias Occidentales. This regulation created the Correos Maritimos between Spain and America ${ }^{20}$, which contained the necessary provisions for the establishment of the new postal system and detailed the procedures for the organization, management and transport of overseas correspondence.

This instruction propagated a new communications infrastructure, linking the Iberian Peninsula to the Spanish American territories through the establishment of post offices in several cities of America, such as La Habana, Puerto Rico, Veracruz, and Cartagena de Indias. These changes included postmasters, alterations in the routes of the overseas mail, adjustments in the methods of transport as well as new taxes. The Reglamento Provisional determined the maritime postal route to be followed: the packet boat would depart from Spain, specifically from the port of La Coruña, on the first of each month, to the La Habana

\footnotetext{
${ }^{17}$ The Bourbon reform has been studied by a good number of authors. The reform has usually been analyzed from a traditional perspective that highlighted the successes of the reforms to a more critical vision who speak about political, social and economic problems and the defects and failures of these reforms whose books concern the obstacles and limits of the Bourbon Reforms. See Luis Miguel Enciso et al., Historia de España. Los Borbones en el siglo XVIII (1700-1808) (Madrid: Editorial Gredos, 1991); Agustín Guimerá, ed., El reformismo borbónico: una visión interdisciplinar (Madrid: Alianza Editorial, 1996); Gabriel Paquette, Enlightenment, Governance, and Reform in Spain and its Empire 1759-1808 (United Kingdom: Palgrave Macmillan, 2008); Clara García Ayluardo, coord., Las reformas borbónicas, 1750-1808 (México: Fondo de Cultura Económica, 2010), Allan J. Kuethe and Kenneth J. Andrien, The Spanish Atlantic world in the Eighteenth Century: war and the Bourbon reforms, 1713-1796 (Nueva York: Cambridge University Press, 2014); Francisco Eissa-Barroso, The Spanish Monarchy and the Creation of the Viceroyalty of New Granada (1717-1739). The politics of Early Bourbon Reform in Spain and Spanish America (Leiden/Boston: Brill, 2017).

${ }^{18}$ Arendt Brendecke, Imperio e información...

${ }^{19}$ For more information see Nelson González Martínez, "Comunicarse a pesar de la distancia: la instalación de los Correos Mayores y los flujos de correspondencia en el mundo hispanoamericano (1501-1640)", Nuevo Mundo Mundos Nuevos (2017), doi: 10.4000/nuevomundo.71527; Manuel Arango Echeverri, Historia Prefilatélica y catálogo de marcas postales de Colombia 1770-1859 (Bogotá: Manuel Arango E., 2018).

${ }^{20}$ Archivo General de Indias (AGI), Correos, 428 A, Disposiciones del superintendente general de correos, marqués de Grimaldi, a los directores generales de la renta, sobre distintas administraciones de correos, 17641765 .
} 
(Carrera de La Habana). Two ships would be dispatched from there: one to Veracruz that would carry the correspondence to Nueva España, and another to Cartagena de Indias that would transport the correspondence through the interior of the south of Spanish America ${ }^{21}$. The implementation of this postal route was motivated by the government's desire to expand governmental control to priority areas of the empire, such as the Caribbean.

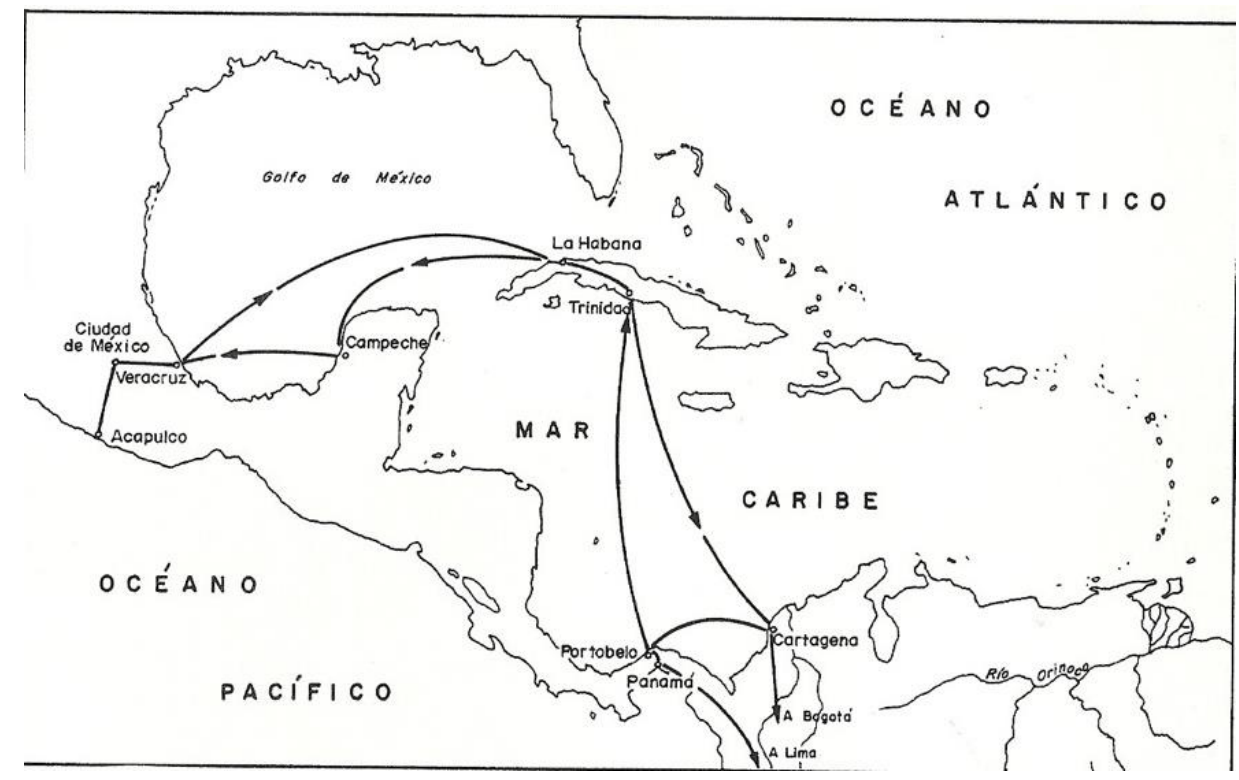

Figure 1. Map showing the maritime and land routes in the Caribbean region in the $18^{\text {th }}$ century. Source: Secundino José Gutiérrez Álvarez, Las comunicaciones en América: de la senda primitiva al ferrocarril (Madrid: Fundación Mapfre, 1993), 342.

Another route called Carrera de Buenos Aires was added in 1767. A packet boat went from La Coruña to Montevideo to carry the letters from there to Buenos Aires on the fifteenth of every other month ${ }^{22}$. These routes had their spatial expression in lines of navigation that aimed to redefine the links between Spain and America, with an organization of the space in function of the communicational nodes and their respective administrative units ${ }^{23}$.

${ }^{21}$ AGI, Correos, 428 A, Disposiciones del superintendente general de correos, marqués de Grimaldi, a los directores generales de la renta, sobre distintas administraciones de correos, 1764-1765.

${ }^{22}$ AGI, Correos, 429 A y 429B. Disposiciones del superintendente general de correos, marqués de Grimaldi, a los directores generales de la renta, sobre distintas administraciones de correos, 1767-1769.

${ }^{23}$ José Araneda Riquelme, “«Una correspondencia mensual, semanaria y a todas horas»: correo y espacio en el imperio español durante las reformas borbónicas, siglo XVIII”, Seminario Simón Collier (Chile, Instituto de Historia de la Pontificia Universidad Católica de Chile, 2014), 50. 


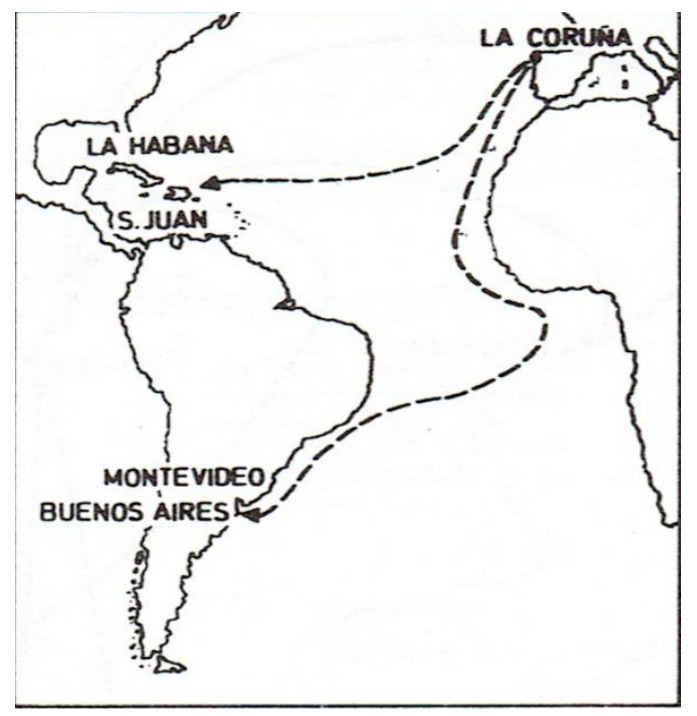

Figure 2. Itineraries for the postal service for the end of the $18^{\text {th }}$ century.

Source: Francisco Morales Padrón, Antonio Rumeu de Armas y Ignacio Tovar, Atlas histórico cultural de América (Las Palmas de Gran Canaria, Comisión de Canarias para la Conmemoración del V Centenario del Descubrimiento de América/ Consejería de Cultura y Deportes, 1988), 561.

\section{Discrepancies with the postal reform project}

The postal reform project was built on a conflictive basis of constant tension. This implied different and complex resistances and oppositions that created struggle for the ambitious postal domain between various power groups. This was due to the fact that these distinct groups felt their position clearly threatened in the role of the circulation of information with the postal reform.

One of the most controversial measures of the establishment of the Correos Maritimos was to locate the main port of entry and exit in La Coruña, to the detriment of Cadiz. Consequently, the first oppositions came from Cadiz, specifically from the institutions mediating Atlantic communication: the Consulado de la Universidad de Cargadores y Comercio a Indias, and the Consejo de Indias. Both organizations strongly disapproved of the creation of the new mail system. This opinion was reflected in several representations made by both institutions on August 21st and 22nd, 1764, in which they justified point by point their disagreement with the governmental initiative of the Correos Maritimos. They noted inconveniences and damages from their perspective, with the aim that the government review the issue ${ }^{24}$. They claimed that it would favor the rotation of correspondence between La Coruña and La Habana while negatively impacting the rest of the American ports. Moreover, they argued that the port of La Coruña was not suitable for this establishment since it was far from the ports of Andalucía where there were importantly the merchants, especially in Cadiz. Hence, these organizations explained that Cadiz should be the main port of the postal system on the Iberian Peninsula and furthermore it should be maintained as the exclusive port for overseas trade ${ }^{25}$.

This fact shows, that the opposition did not agree with the project because it would significantly reduce their control of postal communications with the West Indies. It also

\footnotetext{
${ }^{24}$ AGI, Indiferente General, 1586. Establecimiento del correo marítimo de Indias, 1765-1805.

${ }^{25}$ AGI, Indiferente General, 1586. Establecimiento del correo marítimo de Indias, 1765-1805.
} 
demonstrates that the opposition was not interested in this plan because they wanted to maintain control of communications without direct state intervention.

Behind this crown initiative, was the intention to break the exclusive trade position that Cadiz held as the only port for overseas mail exchange and thus start the decomposition of the Andalusian trade monopoly. Thus, the Bourbon Reforms sought to demolish the autonomy of privileged corporations and deprive them of their dominion over colonial $\operatorname{trade}^{26}$. In this way, postal renewal was part of a wider program of reforms through which the Crown sought to exercise direct control over the government and trade with the Indies to the exclusion of various powerful peninsular institutions: Consejo de Indias, Consulado de Sevilla and Casa de la Contratación. These changes implied an inevitable resistance from the existing actors of the traditional corporate framework, specifically as they saw the conservation of their privileges and particular interests endangered with the enactment of this postal project.

\section{Competition for postal control in Spanish America}

\section{Contradictions by establishment of post offices in the Spanish America}

Post offices were to act as intermediary institutions between the imperial and the local spheres, thus their implementation in different strategic cities, responded to the idea of a decentralized network of post offices interconnected throughout the territory of the Spanish monarchy. For this reason, they were located in the main Spanish American cities. At the head of the post offices would be the administrator, who would be assisted by the chief financial officer to collectively manage the work of that agency ${ }^{27}$. These postmasters would be in charge of coordinating the postal service.

For this purpose, the Postmasters General located in Madrid, selected the individuals they considered most suitable to occupy the new positions in the Spanish American post offices with the aim of influencing who occupied the jobs of the most relevant cities of the Spanish Caribbean. The first postal administrations were located in strategic ports for the Crown such as La Habana, Cartagena de Indias, Puerto Rico, and Veracruz ${ }^{28}$. These port cities were information centers and multidirectional connection nodes.

Most of the candidates had acquired experience in the post offices in Spain where they worked in small offices. Therefore, holding posts in America was a good way to progress in their careers. Moreover, among the aspirants there were family networks that were dedicated to the postal service in important postal administrations of the Iberian Peninsula, who greatly influenced these decisions. This was the case of Roque de Aguión and Andrade, postmaster in Cartagena de Indias, whose brother was the post office administrator of Ferrol ${ }^{29}$. Social networks also had a strong influence on the dynamics of social actors within the postal

\footnotetext{
${ }^{26}$ Gabriel Paquette, "State-Civil Society Cooperation and Conflict in the Spanish Empire: The Intellectual and Political Activities of the Ultramarine Consulados and Economic Societies, c. 1780-1810", Journal Latin American Studies, n. ${ }^{\circ} 39$ (2007): 264-265.

27 AGI, Correos, 428 A. AGI, Correos, 428 A. Disposiciones del superintendente general de correos, marqués de Grimaldi, a los directores generales de la renta, sobre distintas administraciones de correos, 1764-1765.

28 AGI, Correos, 428 A. Disposiciones del superintendente general de correos, marqués de Grimaldi, a los directores generales de la renta, sobre distintas administraciones de correos, 1764-1765.

${ }^{29}$ AGI, Correos, 69 A. Correspondencia de los Administradores de correos de Cartagena de Indias, Roque de Aguión y Andrade, Manuel Balbuena y Antonio Calderón, con los directores generales de la renta y otros, 17641769.
} 
system. Employees tried to make the right contacts in order to obtain influences and privileges in their dealings.

The first post office personal who traveled in the first packet boat, called El Cortés, were Domingo Antonio Lopez, who would occupy the post office in Mexico; Antonio Loñola, in Puerto Rico; Roque de Aguión y Andrade, and Manuel Valbuena, in Cartagena de Indias; José Antonio de Armona, in La Habana; and, José Antonio Pando who was the main post supervisor in the Spanish American territories. These postal personal were mediators in the circulation of information.

Once the postal initiative was established and regulated, it was given the consistent form for its application in the Spanish American territories. However, this postal reform did not have the same implications in all these territories, due to their plurality and complexity. Consequently, the multiplicity and heterogeneity of peculiar features triggered diverse adaptations and configurations in each context, mutually constructing each other in a constant imperial-local dialogue. Within this framework, the unique post office of Cartagena de Indias, constituted an essential node in the imperial postal network and a space for negotiation of Bourbon politics.

In February 1765 Roque de Aguión (as postmaster) and Manuel de Valbuena (as chief financial controller) arrived in Cartagena de Indias ${ }^{30}$. From then on, a new stage was initiated in the organization of the postal system in this city. These postal personnel were obligated to use the regulations and instructions of the higher metropolitan authorities to implement the mail reform in Cartagena de Indias, however there was a big difference between the projected project and the reality.

\section{Disputes over the domain of overland mail}

A few years later, the Crown promoted the postal reform in the interior of Spanish America. The objective was to increase postal coverage in the land routes within the Spanish American territory.

The land mail in the viceroyalty of Nueva Granada and Peru was in the hands of the Correo Mayor de las Indias ${ }^{31}$, Fermín Francisco Carvajal y Vargas. In this situation, family networks also played an important role. Fermín Francisco Carvajal y Vargas possessed this title, due to his marriage with his cousin Joaquina Ana de Brun y Carvajal Vargas ${ }^{32}$. Fermín Francisco Carvajal y Vargas, a native of Quilpolemo in the Kingdom of Chile, was an important figure in America due to his possession of different titles of great political and

\footnotetext{
${ }^{30}$ AGI, Correos, 69 A. Correspondencia de los Administradores de correos de Cartagena de Indias, Roque de Aguión y Andrade, Manuel Balbuena y Antonio Calderón, con los directores generales de la renta y otros, 17641769.

${ }^{31}$ Correo Mayor de Indias was a title held by Galíndez de Carvajal family since 1514, whose residence was in Lima, Perú. He had the monopoly of the mail system in the West Indies in theory but in the practice, he was in charge of the post in the Viceroyalty of the Peru see AGI, Patronato Real,170, R.18. Título correo mayor de Indias: Lorenzo Galíndez de Carvajal. Madrid, 14 de mayo de 1514; y, AGI, Indiferente General, 420, L. 10, f. 133r-137v. Sobrecédula de D. Carlos y Da Juana a los del Consejo, presidentes y oidores de las Audiencias, alcaldes, etc. y a los oficiales de la Casa de la Contratación y de la Casa de la Especiería y al correo mayor y sus lugartenientes para que cumplan la provisión incorporada (Madrid, 14 de mayo de 1514).

32 Joaquina Ana de Brun y Carvajal Vargas, born in Lima, was the daughter of Catalina de Carvajal y Vargas, Correo Mayor de Indias. She married Fermín Carvajal y Vargas in the cathedral of Lima in 1741. Upon her mother's death, she inherited her noble titles and the office of Correo Mayor de Indias. Archivo Histórico Nacional (AHN), AHN, Inquisición, 1289, expediente 18. Informaciones genealógicas de Joaquina Brun de Carvajal y de Fermín Francisco de Carvajal Vargas, su marido, 1761-1762.
} 
military importance, such as that of Mayor of Lima, Colonel of the Cavalry of the Royal Armies and Lieutenant General of the Cavalry of the Kingdom of Peru. They belonged to the Galindez de Carvajal family, which has held the title of Correo Mayor since the $16^{\text {th }}$ century ${ }^{33}$. In this case, there is evidence of the close family and social networks with the function of the postal service, demonstrating that social dynamics and family structure were essential in imperial power structures. This is illustrated in the portrait of Fermín Francisco de Carvajal Vargas in which he appears dressed as an important figure of the Spanish American high society with a letter in his hand that reveals his function as Correo Mayor.

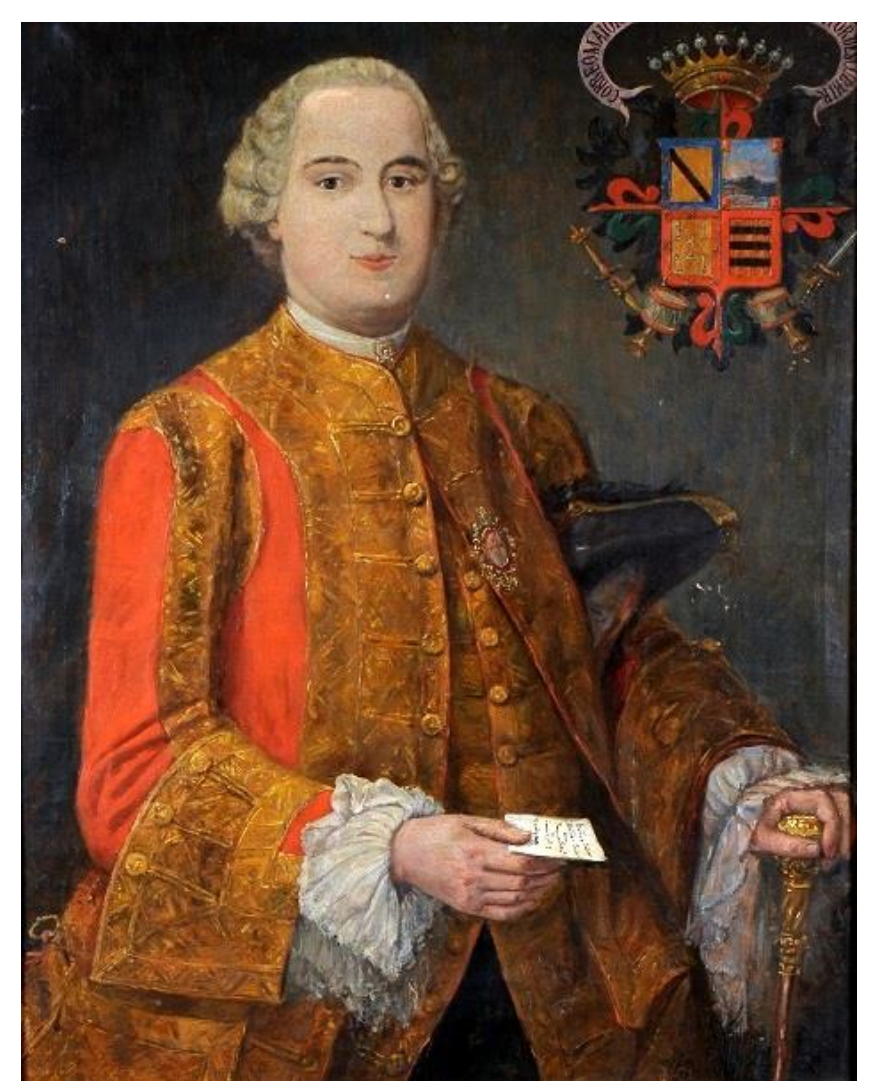

Figure 3. Portrait of Fermín Francisco de Carvajal Vargas y Alarcón, 18th century.

Source: Anonymous. Museo Histórico Nacional de Chile (Santiago de Chile).

Due to the immensity of the territories in its concession, the family Galíndez de Carvajal, could not personally exercise the task entrusted to them. Therefore, they limited themselves in practice to managing the mail of the viceroyalty of Peru, neglecting the rest of the American domains. Thus, in other American spaces, such as Nueva España, Guatemala and Cuba, there were other personnel in charge of mail possession. The conditions of employment in such spaces had different characteristics, since in these cases the post office had a saleable and renounceable character.

\footnotetext{
${ }^{33}$ AGI, Patronato Real,170, R.18. Título correo mayor de Indias: Lorenzo Galíndez de Carvajal. Madrid, 14 de mayo de 1514
} 
The Junta de Incorporación, formed in $1765^{34}$, established strong negotiations with the Correos Mayores and ensured that the Correos Mayores of Nueva España, Guatemala, and Cuba sold their rights to the state ${ }^{35}$. However, the Correo Mayor de Indias could not be incorporated into the Crown unless the owner agreed to transfer out of good will, because it was an appointment for life. This process was extremely arduous and complicated, and the Crown had to make a complex plan for it, full of disputes.

After three years of litigation between the Correo Mayor and the Junta de Incorporación, the Correo Mayor accepted the deal. It included the demand of several rewards, such as the title of Grande de España in perpetuity and that honorific title of Correo Mayor de Indias for the Correo Mayor and his descendants. This complex administrative and judicial process reflected the Crown's interest in reducing the autonomy margins of the Correos Mayores. The result was the abolition of these figures in the overseas Spanish possessions and therefore, the definitive adhesion of these offices to the Spanish monarchy.

The agreement was signed on the $21^{\text {st }}$ of September $1768^{36}$, ending the monopoly the Carvajal family had held as Correo Mayores, and the Crown finally consolidated its plan to rule the maritime and interior correspondence. In addition, it initiated the opening towards a new way of postal organization in the Spanish Americas managed by the Crown, going from the patrimonialization to the institutionalization of this position.

As a result, from 1769 onwards in the postal administration of Cartagena de Indias, as in many other of the Spanish America post offices, sea and land correspondence was handled in a context full of conflict and rivalry for postal handling. This postal system had in practice numerous problems that reduced its control and power. The project had to deal with various obstacles such as the oppositions and resistances of the different actors interested in the postal communication and the geographical conditions.

\section{Limits of the postal reform}

Despite its desire to be a uniform and centralized government, the Spanish monarchy under the Bourbons remained a negotiated empire ${ }^{37}$. This negotiation that took place in the implementation of the reform projects on the ground, constituted an element of autonomy of local action. The dynamics of negotiating positions between the different actors of the empire developed on different scales that interacted continuously at the local and global levels until they reached agreed spaces.

In this sense, the post office in Cartagena de Indias is an excellent observatory of the quality of this phenomenon, which serves to frame this complex process of negotiation and conflict that developed within the margins of the empire. Therefore, postal employees negotiated and disputed local spaces of power in search of the application of the postal service, and their own interests.

\footnotetext{
${ }^{34}$ AGI, Correos, 451 B. Correspondencia y expedientes de la Dirección General de la Renta de Correos, y consultas de la Junta Superior de Correos, 1765-1804.

35 The incorporation of the Oficio del Correo Mayor of Nueva España and Cuba to the Crown took place in 1765 and that of Guatemala in 1767. AGI, Correos, 451 B. Correspondencia y expedientes de la Dirección General de la Renta de Correos, y consultas de la Junta Superior de Correos, 1765-1804.

${ }^{36}$ Archivo General de la Nación de Colombia (AGN), Colonia, Correos, Cundinamarca, Tomo 1, Documento 61. Real Cédula, fechada en San Lorenzo el 13 de octubre de 1768, sobre la incorporación de la Renta de Correos a la Corona, que antes obtuviera el Conde de Castillejo en virtud de cierto título, 1768.

37 Jack P. Greene, Negotiated Authorities. Essays in Colonial Political and Constitutional History (Charlottesville: University Press of Virginia, 1994): 6.
} 
The implementation of the postal reform in Cartagena de Indias provoked reactions among the different political, military, social and economic players affected by the limitation of power and control over the circulation of information that this postal project intended to exercise. In this context, there were constant confrontations between imperial administrators who sought control and local actors who sought greater autonomy to conduct their affairs. However, all parties were seeking autonomy and therefore, there was cooperation between Crown personnel and local forces.

The Bourbon policy of sending Iberian Peninsula officials to America to occupy positions in the Spanish American administration clashed with local forces and interests. This fact was intensified in the first years with the arrival of Iberian Peninsula actors in the city of Cartagena de Indias with the task of taking charge of the post office. This triggered an immediate response from local forces.

This was the case of the confrontation between the first postmaster, Roque de Aguión $y$ Andrade and an official sergeant of the navy, due to the transport of correspondence on boats destined for the peninsula ${ }^{38}$. Moreover, military commanders and the governor of Cartagena de Indias participated in this confrontation and intervened against the postmaster. Roque de Aguión y Andrade was arrested, removed from that administration and assigned to another place on the peninsula ${ }^{39}$. This decision was taken by the high authorities of the peninsula in order not to generate more conflict with the local authorities. The resolution of the conflict reinforces the assertion of sovereignty enjoyed by local actors. It also reflects the Iberian Peninsula government's obligation to negotiate with these forces to maintain balance and the colonial pact in Spanish America, even if it meant revoking its own reformist proposals and measures.

At the same time, there were continuous disputes within the postal administration between different employees who accused each other of malpractice in the postal service ${ }^{40}$. This is the case of the lieutenant of the Correo Mayor, Antonio Calderón, who achieved his aim of occupying the role of postmaster in 1767, after the suspension of Roque de Aguión y Andrade and the renunciation of Manuel Valbuena. Calderón's attitude led him to have confrontations with different actors of the Cartagena de Indias society such as sailors, soldiers, merchants and especially, with high government commanders, such as the governor and the viceroy. These authorities wanted to enjoy a privileged position in the circulation of information and, for this reason, clashed with the management of the administrator.

Antonio Calderón was a resident of Cartagena de Indias with roots in the society of the city. When he became a postmaster, he confronted some members of the maritime corps due to various irregularities, such as the excesses produced by the coastguards of the postal vessels by allowing them to leave without notifying the postal administration. In these circumstances, the governor and the viceroy complained strongly about Calderon's conduct

\footnotetext{
${ }^{38}$ AGN, Colonia, Correos, Bolívar, Tomo 1, Documento 10. Notas de los administradores de correos al Virrey, sobre arribo de navíos con correos y salidas de éstos. Contestaciones del Virrey y asuntos del régimen de ese ramo de la administración pública, 1751-1796.

${ }^{39}$ AGI, Correos, 69 A. Correspondencia de los administradores de correos de Cartagena de Indias, Roque de Aguión y Andrade, Manuel Balbuena y Antonio Calderón, con los directores generales de la renta y otros, 17641769.

40 AGI, Correos, 69 A. Correspondencia de los administradores de correos de Cartagena de Indias, Roque de Aguión y Andrade, Manuel Balbuena y Antonio Calderón, con los directores generales de la renta y otros, 17641769.
} 
and disrespect. This led him to be repeatedly recriminated until he was removed from his post as administrator in May of $1770^{41}$.

These confrontations indicate that the postal administration of Cartagena de Indias was used to produce a clash of interests between the different Iberian Peninsula and local actors in relation to the circulation of information. This was due to the fact that the employees of the post office became an increasingly influential elite due to their access to information and the power that this entailed. Consequently, a web of rejections and collaborations was generated between the different players in the communications apparatus of the Spanish empire that demonstrates the importance of information and the power it represents in the imperial government ${ }^{42}$.

In addition, these cases demonstrate that the Bourbon Reforms collided with limitations that hindered the proper management of the official postal system. In fact, in practice there was a complex power game between the different actors. These clashes demonstrate that reforms aimed at eradicating profit and promoting the professionalization of staff really had limited impact, as Michel Bertrand noted, local authorities ended up impregnating these spheres with their interests and benefits ${ }^{43}$. In this sense, the observed reality reveals the search for mediating elements such as the mechanism that crossed the networks of social links that underpinned the relations of cooperation and competition between postal actors ${ }^{44}$.

This reflects the difficulty that postal actors had in complying with the Iberian Peninsula's regulations in the Indies and the disputes and agreements that took place in the social framework of Cartagena de Indias where the different powers struggled to have control of correspondence. This greatly affected the relationship between communication and empire as it prevented the control of imperial states over their colonial domains. So, the overseas communication of empires continually shifted between the lure of success and the specter of failure.

\section{Conclusions}

The analysis of the documentation of the postal service has allowed us to see how the formation of the overseas mail to Spanish America represented an essential part of the Bourbon Reforms because it was necessary to improve the flow of information within the Spanish empire in order to apply the Bourbon Reform projects. Consequently, the post was an essential tool for the Crown to maintain the communications and govern the overseas possessions. For this reason, the Spanish Monarchy attempted to reform the postal service to control the different channels of information in Spain and America. Therefore, we emphasized the importance of the reform of postal system in the context of Bourbon Reformism which has been unappreciated by historiography, and that was an essential reference for the rest of the transformations enacted by this monarchy. In this way, the postal

\footnotetext{
${ }^{41}$ AGI, Correos, 69 A. Ramo 3, Número 1. Correspondencia del año 1768. "Correspondencia de los directores de la renta a Antonio Calderón”. Madrid, 25 de junio de 1768.

42 Nelson González Martínez, "Correos y comunicación escrita en la América colonial: esquemas de distribución de la correspondencia oficial (1514-1768)", Jahrbuch für Geschichte Lateinamerikas 52, (2015): 59-64.

${ }^{43}$ Michel Bertrand, Grandeza y miseria del oficio. Los oficiales de la Real Hacienda de la Nueva España, siglos XVII y XVIII (México: Fondo de Cultura Económica, 2013): 515-517.

${ }^{44}$ Zacarías Moutoukías, "Negocios y redes sociales: modelo interpretativo a partir de un caso rioplatense (Siglo XVIII)", Caravelle. Cahiers du monde hispanique et luso-brésilien, n. ${ }^{\circ} 67$ (1996): 52.
} 
system became an authentic agent of change through the idea of reaffirming the governmental authority of the Spanish Monarchy with the aim of developing policies in their territories through the consolidation of official channels and means of information circulation.

This plan entailed the creation of various post offices in overseas territories that were responsible for the postal order between Spanish America and the Iberian Peninsula. All those post offices were regulated by numerous orders and instructions between the Postmasters General in Spain and the postmaster in the local Spanish American offices. The main objective was for the government to centralize and exert stronger control over their domains.

However, these attempted postal reforms faced several frustrations that were reflected throughout their development. The postal reform had to negotiate and dispute its attributions within the colonial society with the different actors involved in the circulation of information that revealed how the social actors were structured in practice. Hence, this project was based on clear resistances and complicated negotiations because of the interests of the central authorities that clashed with those of local powers. Therefore, the Spanish Monarchy had to negotiate with different actors, and often to struggle, to apply their reforms plans.

The post was a space of these negotiations among different actors with interests in the postal communication. This configured a set of powers between the central and the local. We argued in this essay, that the projected theoretical reforms faced many problems in their actualization. Some limitations, the Crown could not overcome, while others represented a constant challenge in order to realize their plans. Thus, the reformed postal communication system emerged in a variety of different models and circumstances.

All of this constitutes a clear exponent of how the reformist policies in the different empires were contested and disputed by the local sectors, evidencing the limitation of the power of the Crown in America and the increase in autonomy in the Spanish American space. In this research it is evident how social dynamics intervened in the configuration and intervention of the postal administration of Cartagena de Indias in a context of multiple interests and strategies.

These attempts at reform resulted in a continuous procedure of confrontation and approximation between the different powers that balanced the imperial system based on both conflicts and negotiations and that remained under the premises of a negotiated empire. This has been analyzed from the perspective of the mail reform plan where different agents modeled these renewal projects according to their interests which led to a flexibility of reformist applications in the local terrain.

In short, this research leads us to approaches in which the power and authority of the Bourbon Monarchy was not created by imposition but through negotiation strategies of the parties involved between different centers of power within the Spanish empire. 


\section{Bibliography}

\section{Primary sources}

Archivo General de Indias de Sevilla, España (AGI).

Archivo General de la Nación de Colombia (AGN).

Archivo Histórico Nacional (AHN)

\section{Secundary sources}

Araneda Riquelme, José. "«Una correspondencia mensual, semanaria y a todas horas»: correo y espacio en el imperio español durante las reformas borbónicas, siglo XVIII". Seminario Simón Collier, 27-61. Chile, Instituto de Historia de la Pontificia Universidad Católica de Chile, 2014.

Arango Echeverri, Manuel. Historia Pre-filatélica y catálogo de marcas postales de Colombia 1770-1859. Bogotá: Manuel Arango E., 2018.

Banks, Kenneth. Chasing empire across the sea: communications and the state in the French Atlantic, 1713-1763. Montreal: McGill-Queen's University Press, 2006.

Bauer, Ralph and Marcy Norton. "Introduction: entangled trajectories: indigenous and European histories". Colonial Latin American Review 26, no 1 (2017): 1-17.

Berg, Maxine. Writing the History of the Global. Challenges for the 21st Century. Oxford: The British Academy, 2013.

Bertrand, Michel. Grandeza y miseria del oficio. Los oficiales de la Real Hacienda de la Nueva España, siglos XVII y XVIII. México: Fondo de Cultura Económica, 2013.

Brendecke, Arendt. Imperio e Información. Funciones del saber en el dominio colonial español. Madrid: Iberoamericana, 2012.

Cañizares-Esguerra, Jorge. Entangled Empires. The Anglo-Iberian Atlantic, 1500-1830. Pennsylvania: University of Pennsylvania Press, 2018.

Caplan, Jay. Postal culture in Europe 1500-1800. Oxford: Voltaire Foundation, 2016.

Cardim, Pedro, Tamar Herzog, José Javier Ruiz Ibáñez and Gaetano Sabatini. How Did Early Modern Spain and Portugal Achieve and Maintain a Global Hegemony? Eastbourne: Sussex Academic Press/Fundación Séneca/Universidade Nova de LisboaCHAM/Red Columnaria, 2012.

Conrad, Sebastian. What is global history? Princeton: Princeton University Press, 2016.

Dierks, Konstantin. In My Power Letter Writing and Communications in Early America. Philadelphia: University of Pennsylvania Press, 2009. 
Dubcovsky, Alejandra. Informed power. Communication in the Early American South. Cambridge, Massachusetts and London: Harvard University Press, 2016.

Eissa-Barroso, Francisco. The Spanish Monarchy and the Creation of the Viceroyalty of New Granada (1717-1739). The politics of Early Bourbon Reform in Spain and Spanish America. Leiden/Boston: Brill, 2017.

Enciso, Luis Miguel, Agustín González, Teófanes Egido, Maximilaino Barro y Rafael Torres. Historia de España. Los Borbones en el siglo XVIII (1700-1808). Madrid: Editorial Gredos, 1991.

Fazio Vengoa, Hugo. Escenarios globales: el lugar de América Latina. Bogotá: Ediciones Uniandes, 2003.

García Ayluardo, Clara, coord. Las reformas borbónicas, 1750-1808. México: Fondo de Cultura Económica, 2010.

González Martínez, Nelson. "Correos y comunicación escrita en la América colonial: esquemas de distribución de la correspondencia oficial (1514-1768)”. Jahrbuch für Geschichte Lateinamerikas 52 (2015): 59-64.

. "Comunicarse a pesar de la distancia: la instalación de los Correos Mayores y los flujos de correspondencia en el mundo hispanoamericano (1501-1640)". Nuevo Mundo Mundos Nuevos (2017). doi: 10.4000/nuevomundo.71527.

Grafe, Regina. "Polycentric States: The Spanish Reigns and the "Failures" of Mercantilism". In Mercantilism Reimagined: Political Economy in Early Modern Britain and its Empire, 241-262. Oxford: Oxford University Press, 2013.

Greene, Jack. Negotiated Authorities. Essays in Colonial Political and Constitutional History. Charlottesville: University Press of Virginia, 1994.

Guapindaia, Mayra. "Comunicação e poder: a implantação do Correio Marítimo de 1798 e as respostas dos governos da América Portuguesa". Nuevo Mundo Mundos Nuevos, (2017). doi: 10.4000/nuevomundo.71539.

Guimerá, Agustín, ed. El reformismo borbónico: una visión interdisciplinar. Madrid: Alianza Editorial, 1996.

Gutiérrez Álvarez, Secundino José. Las comunicaciones en América: de la senda primitiva al ferrocarril. Madrid: Fundación Mapfre, 1993.

Hausberger, Bernd. Historia mínima de la globalización temprana. México: El Colegio de México, Centro de Estudios Históricos, 2018. 
Headrick, Daniel R. "Transportation and communication, 1750 to the present". In The Cambridge World History, 401-422. Cambridge: Cambridge University Press, 2015.

Herrero Sánchez, Manuel. "The business relations, identities and political resources of Italian merchants in the early-modern Spanish monarchy: some introductory remarks". European Review of History: Revue européenne d'histoire 23, n. ${ }^{\circ} 3$ (2016): 335-346.

Joyce, Patrick. The state of the freedom. Cambridge: Cambridge University Press, 2013.

Kuethe, Allan J. and Kenneth J Andrien. The Spanish Atlantic world in the Eighteenth Century: war and the Bourbon reforms, 1713-1796. Nueva York: Cambridge University Press, 2014.

Le Roux, Muriel and Richez, Sebastian. Post Offices of Europe 18th - 21st Century. A Comparative History. PIE - Peter Lang S.A., 2014.

Morales Padrón, Francisco, Antonio Rumeu de Armas y Ignacio Tovar. Atlas histórico cultural de América. Las Palmas de Gran Canaria, Comisión de Canarias para la Conmemoración del v Centenario del Descubrimiento de América/ Consejería de Cultura y Deportes, 1988.

Moutoukías, Zacarías. "Negocios y redes sociales: modelo interpretativo a partir de un caso rioplatense (Siglo XVIII)". Caravelle. Cahiers du monde hispanique et luso-brésilien, n. ${ }^{\circ} 67$ (1996): 37-55.

Paquette, Gabriel. "State-Civil Society Cooperation and Conflict in the Spanish Empire: The Intellectual and Political Activities of the Ultramarine Consulados and Economic Societies, c. 1780-1810”. Journal Latin American Studies, n. ${ }^{\circ} 39$ (2007): 263-298.

. Enlightenment, Governance, and Reform in Spain and its Empire 1759-1808. United Kingdom: Palgrave Macmillan, 2008.

Pérez García, Manuel \& Lucio De Sousa, eds. Global history and new polycentric approaches. Europe, Asia and the Americas in a World Network System. Singapore: Palgrave Macmillan, 2018.

Raymond, Joad and Noah Moxham. News Networks in Early Modern Europe. Leiden/Boston: Brill, 2016.

Rojas, Daniel Emilio, ed. Amérique Latine Globale. Histoire connectée, globale et international. París: L'Harmattan, 2017.

Sellers-García, Sylvia, "The mail in Time: Postal Routes and Conceptions of Distance in Colonial Guatemala”. Colonial Latin American Review 21, n. ${ }^{\circ} 1$ (2012): 77-99.

. Distance and documents at the Spanish Empire's Periphery. Stanford: Stanford University Press, 2013. 
Sobral Neto, Margarida. As comunicaçoes na Idade Moderna. Lisboa: Fundação Portuguesa das Comunicações, 2005.

Steele, Ian K. English Atlantic, 1675-1740: An Exploration of Communication and Community. Oxford: University of Oxford Press, 1986.

Subrahmanyam, Sanjay. "Em busca das origens da histórica global". Estudos Historicos 30, n. ${ }^{\circ} 60$ (2017): 219-240.

Thibaud, Clément. "Pour une histoire polycentrique des républicanismes atlantiques (années 1770 - années 1880)". Revue d'histoire du XIXe siècle, n. ${ }^{\circ} 56$ (2018): 161. 